\title{
PRODUCTION OF PCB01, A PLASMID FOR DNA IMMUNIZATION AGAINST THE ADHESIN OF ESCHERICHIA COLI K88AB
}

\author{
Carlos Gil-Turnes ${ }^{1,2 *}$; Fabrício Rochedo Conceição ${ }^{1,2}$; Odir Antonio Dellagostinn ${ }^{1,3}$ \\ ${ }^{1}$ Centro de Biotecnologia (CenBiot), ${ }^{2}$ Faculdade de Veterinária, ${ }^{3}$ Instituto de Biologia, Universidade Federal de Pelotas, RS, Brasil
}

Submitted: August 28, 2000; Returned to authors for corrections: May 09, 2001; Approved: June 28, 2001

\begin{abstract}
Growth characteristics and plasmid yields of Escherichia coli JM109 transformed with pCB01, a plasmid that encodes genes for the fimbrial adhesin of $E$. coli $\mathrm{K} 88 \mathrm{ab}$ and for ampicillin resistance, grown in two culture media in agitated flasks and in fermentor, are reported. The rate of plasmid loss during growth was estimated by the differential counts in media with and without ampicillin. Plasmid yields of cultures grown in flasks varied from 0.9 to $67 \mu \mathrm{g} / \mathrm{ml}$ of medium, while those grown in fermentor attained $62 \mu \mathrm{g} / \mathrm{ml}$ of medium after 8 hours of culture. Plasmid bearing cells were outgrown by plasmid free cells in proportions varying from 5 to 1.2 non-transformed for each transformed cell during growth. Generation times of total population and plasmid bearing cells were 33 and 61 minutes, and 36 and 121 minutes, for fermentor and flask grown cultures, respectively. The same culture grown in fermentor and in flasks produced 62 and $33 \mu \mathrm{g}$ of plasmid DNA per $\mathrm{ml}$ of medium, respectively. Bacterial concentrations and plasmid yields were higher in BHI than in LB medium. Yields of plasmid DNA obtained from the same batch were 1,7 times higher with cesium chlorideethidium bromide gradients than with commercial columns.
\end{abstract}

Key words: plasmid production, genetic immunization, Fae G, Escherichia coli K 88ab

\section{INTRODUCTION}

The development of new products obtained by molecular biology techniques brought new challenges to the industrial microbiologist. Nutritional requirements of transformed cells, rate of spontaneous mutation, outgrowth by mutated progenies, influence of dissolved oxygen and $\mathrm{pH}$, extraction procedures, among others, should be known in order to optimize the technology aiming to obtain efficient products at compatible costs.

Plasmids constructed for genetic immunization are replicated in transformed bacteria. Gooche et al. (6) called attention to the fact that bacteria transformed with a plasmid encoding fimbrial proteins of Escherichia coli had a specific growth rate slightly higher than the cells devoid of the plasmid. The formers were outgrown by the latters in the rate of 1:11 and 1: 122 after the first 24 and 48 hours of culture, respectively, hindering the use of continuous or fed batch cultures.
Although the literature is scarce, few authors reported observations on the behavior of transformed bacteria grown for plasmid replication. Chen et al. (3) reduced the specific growth rate of an $E$. coli strain transformed with plasmids used in genetic immunization from $0.69 \mathrm{~h}^{-1}$ to $0.13 \mathrm{~h}^{-1}$, monitoring the feeding rate and agitation speed of the fermentor.

The objective of the work here reported was to study the behavior of an E. coli strain transformed with $\mathrm{pCB} 01$, a plasmid used for genetic immunization against $E$. coli $\mathrm{K} 88 \mathrm{ab}$, during growth in flasks and in fermentors, and to compare the yield and purity of several extraction procedures.

\section{MATERIALS AND METHODS}

\section{Strain}

The strain used was an E. coli JM109 transformed with pCB01, a plasmid that encodes genes for FaeG, the fimbrial

\footnotetext{
* Corresponding author. Mailing address: Universidade Federal de Pelotas, Centro de Biotecnologia, Campus. 96060-900, Pelotas, RS, Brasil. E-mail: gil@ufpel.tche.br
} 
adhesin of $E$. coli $\mathrm{K} 88 \mathrm{ab}$, and for ampicillin resistance. The procedures followed for construction of the plasmid and for transformation of the strain were reported elsewhere (5). Three transformed strains, showing identical characteristics, were used.

\section{Growth of bacteria}

Lyophilized transformed bacteria were recovered in Brain Heart Infusion (BHI) containing ampicillin $(100 \mu \mathrm{g} / \mathrm{ml})$ and incubated at $37^{\circ} \mathrm{C}$ under strong agitation. Then, the culture was streaked on Brain Heart Agar (BHA) containing ampicillin (100 $\mu \mathrm{g} / \mathrm{ml}$ ) and incubated at $37^{\circ} \mathrm{C}$ overnight. A single colony was used to inoculate a tube containing $5 \mathrm{ml}$ of BHI with ampicillin and incubated overnight at $37^{\circ} \mathrm{C}$ and $250 \mathrm{rpm}$ in a G24 Environmental Shaker (New Brunswick Scientific Co., NJ, USA). This culture was used to inoculate $250 \mathrm{ml}$ flasks containing $50 \mathrm{ml}$ of the same medium, and incubated as reported.

The content of one flask was used to inoculate a fermentor (Multigen F 2000, New Brunswick Sci.), containing $1500 \mathrm{ml}$ of BHI supplemented with ampicillin and antifoam (Silicone 1:5000). The cultures were incubated at $37^{\circ} \mathrm{C}$, agitated at $250 \mathrm{rpm}$ and aerated at $1 \mathrm{vvm}$. Samples were collected at 0, 2, 4, 6, 8, 10, 12 and 24 hours.

The non-transformed E. coli JM109 was grown as reported in media lacking ampicillin.

Doubling time of the cultures were calculated following Pelczar et al. (12), using bacterial counts during the exponential phase.

To study the effect of media composition on plasmid yields, cultures originated from a single colony were grown under identical conditions in BHI and LB. The parental strain E. coli JM109 and the transformed strains were also grown under the same conditions to determine their growth rates in both media.

\section{Determination of plasmid loss}

To determine the rate of plasmid loss during growth, $50 \mu \mathrm{l}$ of decimal dilutions of each sample were plated on BHA with (100 $\mu \mathrm{g} / \mathrm{ml}$ ) and without ampicillin, incubated aerobically at $37^{\circ} \mathrm{C}$ overnight, and then counted. The differences between the counts in both media reflected the number of bacteria that lost the plasmid.

\section{Plasmid extraction}

Plasmids were extracted from each sample by the alkaline lysis method (1) or by the Flexi Prep Kit (Amersham-Pharmacia Biotech). Their concentration was estimated by spectrophotometry at 260 $n m$ and by comparison with a DNA mass ladder (Gibco BRL), and purity by spectrophotometry at 260 and $280 \mathrm{~nm}$. For large scale plasmid DNA extraction, the Birnboim \& Doly method modified for large volumes (8) was used. Purification was performed by ultracentrifugation in a cesium chloride-ethidium bromide gradient or with the Qiagen Plasmid Mega Kit (Qiagen, Max Volmer Strasse 4, 40724, Hilden, Germany).

\section{RESULTS}

Yields obtained in flasks showed great variations among batches, ranging from 0.9 to $67 \mu \mathrm{g}$ of plasmid DNA per ml of medium. When the bacteria were grown in a fermentor, the yields varied through the growth period, reaching $62 \mu \mathrm{g}$ after 8 hours of incubation, four hours after the end of the logarithmic phase (Table 1). The concentration of plasmid DNA remained almost stable during the early stationary phase, but it dropped below the initial values after 24 hours of incubation, despite an increase in optical density.

A typical growth curve of the transformed strains grown in fermentor is shown in Fig. 1. As it can be seen, during the exponential phase, that ended after 4 hours of growth, plasmid free cells outgrew those carrying plasmids, in proportions varying from 5 to 1.2 non-transformed for each transformed cells.

Generation times of cells grown in fermentor were 33 and 61 minutes for total population and plasmid bearing cells,

Table 1. Culture of $E$. coli transformed with $\mathrm{pCB} 01$ in a bench scale fermentor.

\begin{tabular}{cccccc}
\hline Hours & total $^{*}$ & resistant* & OD $_{600}$ & pCB01** & total/resist \\
\hline 0 & 7.5 & 7.5 & & 2.8 & $1 / 1$ \\
2 & 7.6 & 7.6 & 1.109 & 34 & $1 / 1$ \\
4 & 8.7 & 8.2 & 1.219 & 48 & $3 / 1$ \\
6 & 8.5 & 8.2 & 1.303 & 47 & $2 / 1$ \\
8 & 8.3 & 8.2 & 1.338 & 62 & $1.2 / 1$ \\
10 & 7.9 & 7.2 & 1.315 & 61 & $5 / 1$ \\
12 & 7.3 & 6.8 & 1.283 & 60 & $3 / 1$ \\
24 & 5.6 & 5.6 & 1.603 & 31 & $1 / 1$ \\
\hline
\end{tabular}

* $\log$ viable count; ** $\mu \mathrm{g} / \mathrm{ml}$ of medium.

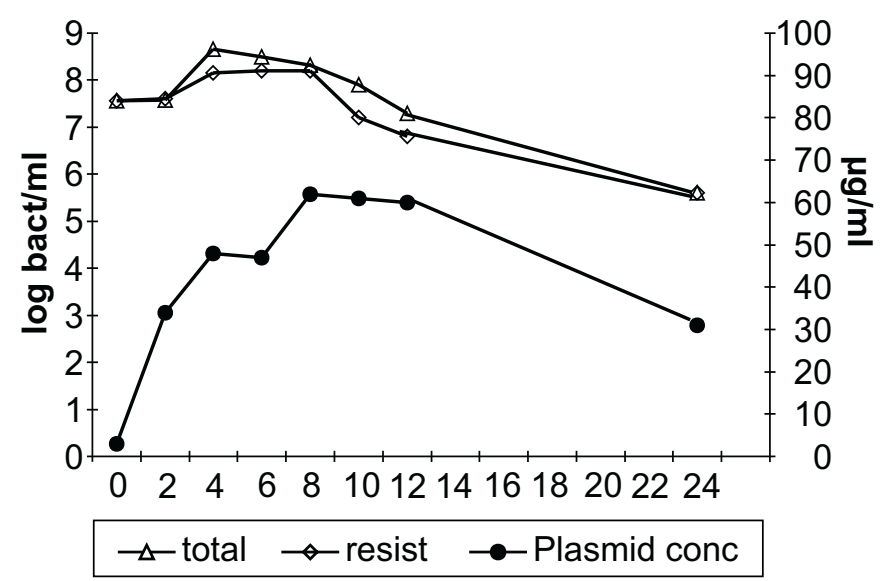

Figure 1. Growth of E. coli JM109 transformed with pCB01 in fermentor. Total count and count of plasmid bearing bacteria. Plasmid concentration in $\mu \mathrm{g} / \mathrm{ml}$. 


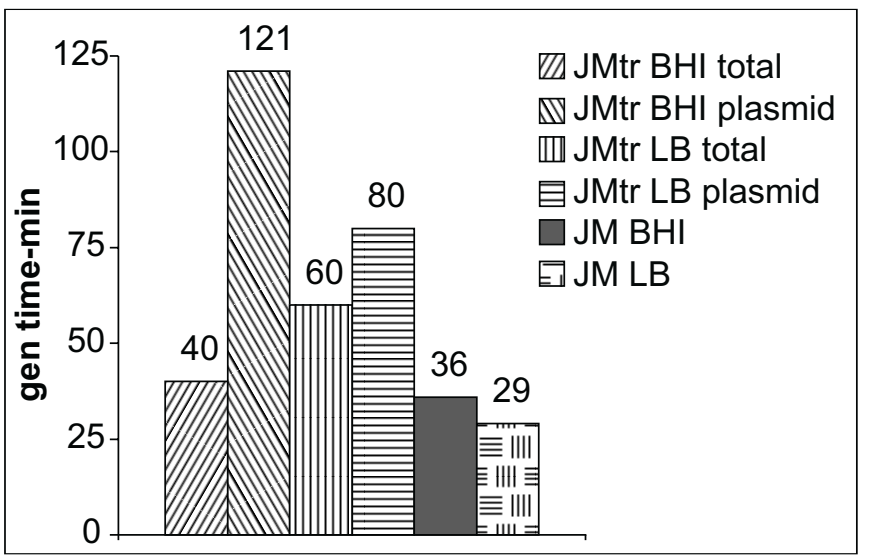

Figure 2. Generation times of $E$. coli JM109 transformed with pCB01 (JMtr) in BHI and LB media, with (plasmid) and without (total) ampicillin, and E. coli JM109 (JM) non-transformed.

respectively. Those of the same strain grown in flasks with agitation, were 36 and 121 minutes, respectively. Plasmid yields at 8 hours of culture were 62 and $33 \mu \mathrm{g} / \mathrm{ml}$ of medium for cultures grown in fermentor and in flasks, respectively.

Fig. 2 shows that in BHI the generation times of the parent strain is slightly lower than in the total population, and four times less than in plasmid bearing progenies. The same was observed in cultures grown in LB, but the differences among them were lesser. The generation times of the parental strain and of plasmid bearing cells were shorter in LB than in BHI.

Bacterial concentrations of the same culture during the exponential phase of growth were higher in BHI than in LB, while plasmid yields were $33 \mu \mathrm{g}$ and $7 \mu \mathrm{g}$ per $\mathrm{ml}$ of medium, respectively.

Yields of plasmid DNA obtained from $500 \mathrm{ml}$ volumes of the same batch with cesium chloride-ethidium bromide gradients were 1.7 times higher than those obtained with Qiagen Plasmid Mega Kit.

\section{DISCUSSION}

Scaling up transformed bacteria need a comprehensive knowledge of the behavior of the strains, including, among others, nutritional requirements, rate of plasmid loss and generation times of plasmid bearing and plasmid free progenies. In addition, extraction and purification procedures that are used when small amounts of bacteria are processed, may not be suitable for larger volumes.

Gooche et al. (6) showed that differences in generation times of plasmid free and plasmid bearing cells during fed batch or continuous cultures, could lead to the extinction of transformed progenies due to their outgrowth by progenies that lost the plasmids. The transformed $E$. coli they used was outgrown in rates of 1:11 and 1:122 after the first 24 and 48 hours of culture, respectively, by progenies that spontaneously lost the plasmids, hindering the use of continuous or fed batch cultures. This problem seems not to be so crucial in batch grown bacteria.

Plasmid bearing cells showed much higher generation times than both, the parental strains and cells that lost the plasmids during growth. Our data suggests that dissolved oxygen may be related to these differences, since the generation time of plasmid bearing cells grown in flasks was twice that of those grown in fermentor, while those of plasmid free cells was almost the same in both systems. The rate of cells with and without plasmids remained stable after they reached the stationary phase, suggesting that at this stage the generation times became equal for both progenies. The end of plasmid synthesis shortly after the completion of the logarithmic phase, probably due to nutritional restraint, may explain the maintenance of these rates during the period of observation. Maximum plasmid yields of the carboxydotrophic bacteria Pseudomonas carboxydovorans and Alcaligenes carboxydus, were also produced at the beginning of the stationary phase (11).

Plasmid yields of cells grown in fermentor were twice those of agitated flask, suggesting that oxygen supply may also be related with this difference. Air was supplied at a rate of one volume of air per volume of medium per minute in the fermentor, but it was not renewed in flasks. This means that over an 8 hour growth period, the rates of air per volume of medium were 480/ 1 and 4/1 in fermentor and flask grown bacteria, respectively. Dissolved oxygen concentrations affected the stability of a recombinant $E$. coli, showing that after a short period of reduction the number of plasmid free cells outgrew in two or three orders of magnitude those of recombinant cells (9). Similar findings were reported with transformed Saccharomyces cerevisiae (2). Our experiments also showed that during the logarithmic phase of growth plasmid free cells outgrew plasmid bearing cells in magnitudes that varied between $1.2 / 1$ to $5 / 1$.

Besides dissolved oxygen, media composition may also influence plasmid yield. In our experiments, yields obtained from cells grown in BHI were 4.5 times higher than those grown in LB.

The importance of fulfilling the nutritional requirements of transformed bacteria was also shown by Chen et al. (3) that were able to manage the generation times of a transformed $E$. coli in continuous culture experiments modifying feeding rate and agitation speed.

Although the intimate mechanisms of plasmid replication continue under study, there is evidence that lower consumption of energy and metabolites by plasmid free cells than by plasmid bearing cells may be involved in the differences in generation times and plasmid yields reported above. Reinikainen et al. (13) showed that transformed $E$. coli required different conditions of growth than plasmid free progenies, and that plasmid copy number could be influenced by the growth rate. 
The replisome of DNA, necessary for the replication of both the chromosomal and plasmidial DNA, is as large as a ribosome, involving more than 40 proteins (10). In addition DNA gyrase, the enzyme responsible for the formation of negative supercoils, the natural state of almost all plasmids inside their hosts, and a partition complex formed by two other proteins, are required for the stable inheritance of several plasmids. High copy number plasmids can compete with the host for metabolites, resulting in decreased cell viability and the subsequent loss of plasmids (4).

Our experiments showed that the peak of plasmid yield was obtained around four hours after the end of the logarithmic phase. This phase was surprisingly short, probably because we used inocula in late logarithmic phase during scaling up. Plasmid concentration remained stable for a short period, but it was reduced to half the maximum value at 24 hours of culture, possibly due to lysis of plasmid bearing cells. The inverse relationships between optical density and plasmid concentration detected during the decline phase in our experiments indicate that optical density is not suitable to monitor plasmid yields.

Another observation that is worth to point out is that methods used for plasmid extraction from small volumes of culture may no be the best choice for large ones. Yield rates obtained with miniprep kits were substantially lower than with cesium chlorideethidium bromide gradients or the Qiagen Plasmid Mega Kit. When we used these methods for the extraction from half liter volumes, the yield obtained with the gradient method was 1.7 times higher than that obtained with columns. On the contrary, Griffith (7) obtained yields four times higher with commercially available columns than with cesium chloride-ethidium bromide gradients, being the purity of the preparations also higher with the former. It must also be pointed out that, in our conditions, plasmid extraction costs were four times lower with cesium chloride-ethidium bromide gradients than with columns.

Our results emphasize the need to optimize culture and extraction procedures in order to obtain plasmids for genetic immunization at compatible costs.

\section{ACKNOWLEDGEMENTS}

This research was supported by Conselho Nacional de Desenvolvimento Científico e Tecnológico $\left(\mathrm{CNPq}\right.$, grant $\mathrm{N}^{\mathrm{o}}$ 520107/96/9) e Fundação de Apoio à Pesquisa do Rio Grande do Sul (FAPERGS, grant No 98/0228.5).

\section{RESUMO}

\section{Produção de pCB01, um plasmídio para imunização genética contra a adesina de Escherichia coli K88ab}

Comunicam-se algumas características de cultivo e a produção de plasmídios por Escherichia coli JM109 transformada com pCB01, um plasmídio que codifica os genes da adesina fimbrial de $E$. coli $\mathrm{K} 88 \mathrm{ab}$ e de resistência à ampicilina. A cepa foi cultivada em Infuso de Cérebro e Coração (BHI) e em caldo de Luria (LB), em Erlenmeyers agitados e em fermentador de bancada. A taxa de perda de plasmídios foi estimada pela diferença de contagens em meio com e sem ampicilina. Os rendimentos de plasmídios das culturas em Erlenmeyer variaram de 0,9 a $67 \mu \mathrm{g} / \mathrm{ml}$ de meio, entanto as cultivadas em fermentador alcançaram $62 \mu \mathrm{g} / \mathrm{ml}$ após 8 horas de cultivo. Células sem plasmídio superaram às transformadas de $5 \mathrm{a} 1,2$ vezes durante o cultivo. Os tempos de geração da população total e das células transformadas foram 33 e 61 minutos no fermentador, e 36 e 121 minutos em Erlenmeyers, respectivamente. O mesmo inoculo produziu 62 e $33 \mu \mathrm{g}$ de plasmídio por $\mathrm{ml}$ de meio no fermentador e em Erlenmeyers, respectivamente. As concentrações de bactérias e o rendimento de plasmídios foram superiores em BHI que em LB. O rendimento de plasmídios obtidos do mesmo cultivo foram 1,7 vezes maiores quando a purificação foi feita pelo método de ultracentrifugação em gradientes de césiobrometo de etídio do que com colunas comerciais.

Palavras-chave: produção de plasmídios, imunização genética, Fae G, Escherichia coli K 88ab

\section{REFERENCES}

1. Birnboim, H.C.; Doly, J.A. Rapid alkaline extraction procedure for screening recombinant plasmid DNA. Nucleic Acids Res., 7:1513$1522,1979$.

2. Caunt, P.; Impoolsup, A.; Greenfield, P.F. The effect of oxygen limitation on the stability of a recombinant plasmid in Saccharomyces cerevisiae. Biotechnol. Lett., 11:5-10, 1989.

3. Chen, W.; Graham, C.; Ciccarelli, R.B. Automated fed-batch fermentation with feed-back controls based on dissolved oxygen (DO) and $\mathrm{pH}$ for production of DNA vaccines. J. Ind. Microbiol. Biotechnol., 18:43-48, 1997.

4. Firshein, W.; Kim, P. Plasmid replication and partition in Escherichia coli: is the cell membrane the key? Molecular Microbiol., 23:1-10, 1997.

5. Gil Turnes, C.; Aleixo, J.A.G.; Monteiro, A.V.; Dellagostin, O.A. DNA inoculation with a plasmid vector carrying the fae $G$ adhesin gene of Escherichia coli K88ab induced immune responses in mice and pigs. Vaccine, 17:2089-2095, 1999.

6. Goochee, C.F.; Hatch, R.T.; Cadman, T.W. Some observations on the role of type 1 fimbriae in Escherichia coli autoflocculation. Biotechnol. Bioeng., 29:1024-1034, 1987.

7. Griffith, O.M. Large scale isolation of plasmid DNA using high speed centrifugation methods. BioTechniques, 6:725-727, 1988.

8. Hardy, K.G. Plasmids: a practical approach. I.R.L. Press Ltd., Oxford, England, 1987, 188p.

9. Hopkins, D.J.; Batenbaugh, M.J.; Dhurjati, P. Effects of dissolved oxygen shock on the stability of recombinant Escherichia coli containing plasmid pKN401. Biotechnol. Bioeng., 29:85-9, 1987.

10. Kornberg, A.; Baker, T. DNA replication. $2^{\text {nd }}$. ed. San Francisco: W.H. Freeman \& Co., 1992.

11. Kraut, M.; Meyer, O. Plasmids in carboxydotrophic bacteria: physical and restriction analysis. Arch. Microbiol., 149:540-546, 1988.

12. Pelczar, M.J.; Chan, E.C.S.; Krieg, N.R. Microbiology, Concepts and Applications. McGraw-Hill, New York, 1993, 896p.

13. Reinikainen, P.; Korpela, K.; Nissinen, V.; Olkku, J.; Söderlund, H.; Markkanen, P. Escherichia coli plasmid production in fermentor. Biotechn. Bioeng., 33:386-393, 1989. 